\title{
Globalization: Is There Anything to Fear?
}

Daniel Drache, Director of the Robarts Centre

York University, Toronto

October, 1998 


\title{
Globalization: Is There Anything to Fear?
}

\author{
Daniel Drache
}

\section{Introduction}

Long before the Internet and the modern information revolution, the belief in the triumphant world market occupied a privileged place in modernity. In every age, global competitive pressures have threatened to topple established state hierarchies and give new property rights to some while stripping others of their meager economic security. If we understand anything about the pursuit of this vision, it is that the globalization narrative has an unlimited capacity to reinvent itself in a new guise when conditions demand it. Today is one of those defining moments. Markets are no longer deemed to serve any larger purpose in accommodating full employment objectives or the other equity issues that until recently imposed limits on market forces. Instead the natural impulse of government is not to withdraw from the world economy but to embrace it as the short twentieth century is coming to an end and as a new kind of state is emerging with its own forms and institutions. In the new era of global competition, its most powerful mantra is that of one world-ism as opposed to jobs for everyone. State policy requires a very different kind of political grammar from the internationalist discourse of the Cold War era. ${ }^{1}$

\section{The Definitional Quandary}

The first strategic question is how should we understand the principal dynamics and core characteristics of the new era of global competition? As an out-of-control bulldozer, sweeping everything out of its path, dis-empowering for rich and poor nations alike? (Barnet and Cavanagh, 1994) As freedom of capital flows? "A world in which people are able to put their money where ever they wish." (Wolf, 1998) As a radically redefined world where we are "all interdependent in a global market place"? (Dahrendorf, 1995) As a trade regime that is fundamentally "about integration and the competitive pressures to build mega-markets"? (Cable, 1995) As geo-politics? - triumphant US liberalism and "its capacity to externalize its national policies globally." (Blank, 1994) As the growing importance and increased role of exports in national economies? (Bairoch. 1996) As the end of the Keynesian state and its interventionist strategies to shape markets? (Boyer and Drache, 1996) As the core element of the technological revolution? - the enormous benefits that result from the massive introduction of labour saving technologies that alter fundamentally the way goods and services are

${ }^{1}$ The 'old world order' was a multilateral system that required countries to agree on a number of commonly-held fundamentals - international co-operation via the Bretton Woods institutions such as the World Bank, IMF and the GATT; international development spurred by the expectations of the UN development decade and the power of the non-aligned countries to negotiate state to state assistance; international governance by non-market international organizations such as the ILO, FAO and UNESCO to create codes, norms and other regulatory standards; and, finally, strong market-limiting policies by states themselves. (Haas, 1995; Report on World Governance; Ruggie, 1982) 
produced. (Rodrik, 1997) Or, is it about the long-term irreversible developments? - the wholesale change in spatial and temporal arrangements that are redefining existing state-market relations from the top to the bottom for developing and advanced economies alike?

Beyond the transformation of state policy, the world-wide movement of economic liberalization and falling trade barriers invokes something else - an age of diminished expectations and a powerful restatement of classic liberalism. (Brittan) With the resurgence of liberalism as the standard for all countries, Western society is marked by a threshold event, " the revolt of the elites and the end of the democratization of wealth ." (Lasch, 1994) Elites no longer want to pay for services that they can provide for themselves. It is this ideology with the psychological imperative of the elites' need to convince themselves that the new global pressures require drastic new practices on the part of governments and corporations which is redrawing the boundaries between public and private within states everywhere.

It is easy to understand why scholars of the Left persuasion consider that the global corporation is at once the principal agent, architect, villain and major beneficiary of the new world order. It is the sole dedicated actor that is in a position to benefit directly from the dramatic changes that are occurring. There is much evidence that in Sylvia Ostry's words, "the power of the nation state is eroding from above, by globalization and from below, by devolution”. (Ostry 1998) Established class relations are crumbling as private sector actors have created "a world without frontiers that only advantages corporate greed." (Citizens for a Corporate Renaissance, 1998) The ubiquitous power of the multinational enterprise is one of the key features of investment-driven globalization. Yet, with so many factors challenging the nation-state and with so many definitions jostling and competing for attention, is this not the quintessential Pirandello effect -- seven, eight or ten definitions in search of a single phenomenon ${ }^{2}$ If experts cannot agree on its basic features, no wonder that public can is confused and baffled.

The puzzle is that for the last five hundred years, the world's countries have already been part of the international economy selling goods, exchanging ideas and host to the waves of immigrants. Wallerstein is unquestionably right that all throughout that long sweep of history, the international market has functioned like a giant magnet encroaching on national space and practice. (Wallerstein, 1974: Modelski, 1972) Sovereignty was never absolute except in the minds of legal scholars like Dicey and others.( Picciotto, 1998) E. H. Carr, the brilliant public intellectual and scholar made the case that even at a time of beggar-thy-neighbour policies interdependence was always the rule and sovereignty the exception. (Carr, 1939 and 1981) Powerful imperial-minded states defined their

${ }^{2}$ From another perspective the Pirandello effect is irrelevant for the public. Public opinion is not agitated by scholarly debate but are alarmed by the fact that the globalization narrative cum public discourse has won the hearts and minds of most of the media, international organizations and corporate elite the world over. Public opinion polls reveal that elites are often gang-buster supporters of globalization while the public is hostile to the idea that corporations should be granted new rights. The anti-NAFTA and anti-EU populist sentiment is always the wild card threatening to derail these giant projects from going to the next level of integration. 
sovereignty as a matter of right; the less fortunate found their sovereignty limited by geopolitical realities; the least favoured people found themselves entrapped by colonialism and their sovereignty destroyed by ruthless imperialist expansion. (Hobsbawm, 1996)

So the generalization that in no era has the world market not reached relentlessly behind the frontiers of nation states to challenge the authority of national government and to constrain them is dead accurate. Faced with the constant encroachment by international capital and business organization, states everywhere have always had to develop policy instruments that allowed them to co-exist with the international economy not easily but as a fact of life -- a given of politics no less than economics.

If globalization - 'aint unprecedented.; aint new; and aint unique', converging events are driving the world market faster and further than ever. The threshold issue is that with the collapse of the Soviet Union, the system of capitalism has triumphed everywhere against its historic enemy -socialism. Hayek is back and Keynes and Beveridge are thought to be yesterday's men. The victors are the market economies that are the sole economic system in the world today with their own set of benchmarks and norms, a prototypical state and international organizations responsible for the new world order. Triumphant liberalism of the Anglo-Saxon kind wants to remove all barriers to market growth and practices. (Bergsten, 1996) More than this, it wants to take the state out of the market and extend its norms and practices into civil society. The common condition it seeks is people enlarging their freedom through investment rights by living in a world that is self-created, not statedominated. Even if the state is not about to fade away, powerful public and private entities are intent on changing our fundamental preoccupation with territoriality and identity. (Cable 1996)

The emergence of the global economy is the watershed event of our times. The question is, can governments and policy experts learn to think in a reasoned and critical way about the limits of global free trade? Or, will they will continue to fear what they do not understand, engage in unnecessary risk-taking and be unable to react strategically to such complex changes in the international economy?

\section{The Argument in Brief}

The following paper sets out to elucidate a core idea, namely that globalization in its many different forms and reiterations is the last grand narrative of the $20^{\text {th }}$ century. It evokes a universal vision of frictionless adjustment, endlessly innovative corporations, infinite progress and unlimited abundance for all through the power of the world market. What is particular about the latest tidal wave 'where all are interrelated through the global market' is that it is not a popular force capable of mobilizing millions in the way working class internationalism once did. (Sassoon,1996) Nor does it have any interest to strengthen democratic institutions or to give communities more resources. It has no core redistributive values that promise to address inequality domestically or internationally. It is not participatory other than for a powerful group of global corporations and it shares nothing in common with the collective aims of liberalism which promise individual and cooperative betterment through state reform. But it has a powerful vision of the future; a program of action; an agenda for governments; and a demanding set of policy objectives that have made it the most potent force 
redefining state policy and elite governance everywhere.

With the world at such different stages of development and with such different economic systems, it remains an open question whether the contemporary global free trade regime can sustain itself as presently constituted. It is not a foregone conclusion that the global economy will come undone and crash but what is clear is that financial deregulation has gotten out of hand. Despite the triumphant nature of markets in Anglo-Saxon economies that have irreversibly altered the fundaments of economic and social policy management in many jurisdictions, there are still strong grounds for claiming that the world price system does not automatically build a level playing field across nations as its rhetoric claims. (Boyer, 1996a)

So far, the price mechanism has not produced the expected convergence between social market, laissez-faire, developing economics and Asia-Pacific. Governments ought to be highly vigilant in times of speculative booms, quick fixes that turn bad and too much easy money flowing across border but increasingly they are not. They have misunderstood the importance of the regulatory need to organize the market. The collapse of the miracle economies (once touted to last for decades) -- Mexico in the early 80 s and more recently the Asian Tigers along with the former Eastern Bloc countries -underlines the fragility of the existing order. Divergence at all levels is increasingly becoming more important as a feature of globalization despite the powerful authority of elite international institutions to move the global agenda towards the market end of the spectrum.

The persistence of national governance capacity, the emergence of strong regional movements with roots in non-market institutional arrangements as well as the deep-rooted appeal of identity politics that empower people and reinvent the 'local' in diverse and unpredictable ways, all hold out the promise of a different kind of world order from the current one. As the globalization debate enters a new critical phase, policy elites should listen to the advice of Joseph Stiglitz, chief economist at the World Bank given in a recent address. The bottom line, he warned, is that stability at any cost is simply the wrong target. (Stiglitz, 1998). If he is right, the political market for social protection -jobs and a higher standard of living -- promises to be a more potent force than the most arduous tenets imposed by the dynamics of a laissez-faire globally-directed free trade regime.

To understand why this is so, let us begin with the phenomenon of globalization itself - trickster, puzzle, dominant narrative of new state forms and practices. What is being globalized? what remains rooted in national practice and custom? and, most importantly, what are the kinds of tools that policymakers need to address the increasingly complex distributional, environmental and social issues at the end of the millennium? (Rosenau, 1997;1996) Once this is done it will be possible to understand a second and related concern that the raw power of capital over labour is stoppable and these new global forces can indeed be slowed down, redirected, and even mastered by governments once when they learn to manage the complexities of structural change.

\section{Its Death-Like Images and Language: The Fundaments}

Why should the globalizing economy evoke 'the end of state authority`, 'the end of economic 
geography`, the 'demise of the nation-state', 'the melt down of the global financial system', ' the end of work', the world city-hypothesis of accommodating global capital at any price and other deathlike images and language? ? $^{3}$ What evidence is there that global forces are indeed dismantling the physical barriers that limit capital accumulation on a world level? (World Investment Report, 1992) Why has public discourse gone overboard in accepting that the circulation of capital and goods is largely conducted beyond the reach of any one state? (World Bank, 1997)

The argument is typically framed in terms of the assumed and automatic advantages that inhere in the world's open trading system:

- the emergence of globally organized production and the instantaneous transfer of money is entirely new and so pervasive that it breaks down the firewalls between the local and the global. Do we accept this as an absolute truth? Or is it more accurate to understand that the new world economy is only partial and the global circulation of goods is not occurring on a world-wide basis, but mainly between Europe, North America and Japan accounting for more than eighty percent of the exports and foreign direct investment flows between them? Despite the massive growth of exports, not all countries and regions are being integrated into the world market. At best globalization is only partial and uneven.(Group of Lisbon, 1995)

- globalization is experienced uniformly across regions, nations and continents based on the laissezfaire model Anglo-American experience. Just when all people need the nation-state as a buffer, it appears to be deserting them. Everywhere the powerful forces of globalization are redefining the norms and practices of governments. But is the reverse also the case, that divergence in industrial relations practices, social policy and state expenditures between the social market countries, developing nations and Anglo-American economies is as pronounced as ever? If it is so, why have divergent state policies emerged in so many countries? (Pauly and Reich, 1997; Weiss, 1998)

- the new competitive pressures challenge the political boundaries of all communities. Or is the opposite closer to the truth? Only in a limited number of countries are elites arrayed against the state and its principal institutions - the labour market first of all because labour practices are deemed rigid and anti-market; social policy because it is attacked as being too generous and too costly; and cultural policy stigmatized as being narrowly nationalistic and a barrier to the free movement of ideas! Or are these changes in the size and role of the welfare state that all countries are presently experiencing much more relative and contingent rather than as absolute and dramatic as they are believed to be in

${ }^{3}$ It is a puzzle because optimism should be the hallmark of the global revolution; but it is not. Instead uppermost in the minds of many experts are fears of its collapse. (Bergsten, 1996) Political elites have often capitalized on these fears to make highly dramatic appeals and call for 'deep integration' as 'the urgency for competitive liberalization has accelerated.' 'Sign the NAFTA. There will never be another opportunity.'; 'The Uruguay Round is a life or death situation.'; 'A defeat of the US Administration's demand for ' fast track' approval stops hemispheric integration cold.' Monetary union must go forward as planned; no postponement is possible.' 
popular discourse and the current outpouring of academic articles? (Esping-Andersen, 1997 )

- globalization strengthens principally the coercive powers of the state by deregulating labour markets, spending less and taxing less. Or instead is it the case that markets also have a levelling effect on state authority, if not by intent, then as a consequence of identity politics and the new social movements? Keynes and Beveridge may be dead but everywhere social movements are confronting state authority and deregulated markets in surprising new ways and often with greater effectiveness than many believe. (Lyman, 1995)

- the nation-state is a spent force. With more nation-states in the world today than any time previously, the post-national nation-state is a contradiction in terms for most of the world's peoples. Public authority continues to be the most effective manager of the planet today, having responsibility for well-being, safety, the environment, social capital, health and education. The challenge is to make the nation-state more responsive and accountable, transparent and effective as a manager of a country's resources and well-being. This is why in all jurisdictions, the res publicae of governance remains public finance and spending on human capital and not pure market logic. (Drache, 1997)

- the architects of the global order are the transnational corporations endlessly innovative, farsighted entities that have the organizational capacity to exploit the new global economy as an 'unparalleled opportunity. Gaining global competitiveness, learning to exploit these economies of global scale and adapting to local market differences are not straightforward or automatic as the theorists claim. Many global giants are beginning to grasp that they are not 'kings of the road' but are at perilous risk. These global players are not in control, are unable to exploit many of these changing technologies and have not been able to shield themselves from the volatile and unpredictable global business cycle. Is there any solid empirical evidence that firms and nations are indeed reorganizing themselves to serve the world market instead of the local one? (Lester, 1998)

- finally, that globalization is not largely the millennium project of a transnational business class but of states themselves. In that case, what are the principal characteristics of the prototypical state that sets the standards and benchmarks for others? Are there dumb ways to compete? Are there smart ways?(Kay, 1996)

\section{The 'New Rules of the Game' That Cause States to Rethink Public Policy and State Market Relations}

Beyond these questions, the bottom line is that while this is not a new epoch in human history, it constitutes a radical break with the established public policy framework of the last five decades. Competitive liberalization has resulted in the dismantling of many of the barriers that traditionally limited capital accumulation on a world scale. Elites have accepted the idea that 'one last big push' is needed to ensure that the high-income economies of Europe, North America and Japan and the lower-income countries take the next step to ensure that the momentum continues. The trade reforms of the last decade need to be locked in so that there is no going back to the old order that gave every state a large discretionary role to limit markets and investors' rights for national ends. (Drache, 1998) 
It is this seminal idea which is at the heart of what is happening in so many jurisdictions. And, it is also why the current phase is so dissimilar from the Bretton Woods design for an international economy. The multilateral trading order was largely based on its compatibility with the nation-state system where trade and investment flows and the process of accumulation reinforced rather than subverted national authority. (Adda. 1996) Now that tariffs have fallen close to zero for most goods, the circulation of goods and capital is conducted beyond the reach of any one state. In the intersection where sovereignty and territoriality collide, these are the new rules of the game driven by markets, elites and powerful private actors. (Strange, 1995; Sassen, 1996; Cable, 1995)

- A growing incompatibility between the nation-state and production and investment. More and more investment and production are taken by firms outside the national economy. What is different is that most industrial countries relied on their exports as a critical component of wealth and job creation. Exports were only one of the drivers of the wealth of nations; now exports have become the driver par excellence of the economy for goods and service production. (Ostry, 1996)

- Asymmetry between exports as the driver of the economy and stagnant domestic GDP growth. The export-side of the economy continues to boom while domestic growth remains flat by comparison throughout the industrialized world. In many countries, there is a structural imbalance in the disproportionate growth in exports to the world market and the absence of strong growth regionally and nationally. In the past trade was perceived as an export enhancing activity that reinforced a Fordist system of mass production. Lower tariffs, longer production runs and cheaper goods were seen to generate an endless stream of high paying jobs. Now trade is job destructive for many industries as firms have to cut costs, trim payrolls and shorten commodity cycles. (Rodrik, 1997)

- The revolt of the elites and the end of the democratization of wealth. Redistributive polices protected the lowest income earner from the business cycle and joblessness but they do no longer do so to the same degree nor do they cover as many people. Elites do not want to pay for these programs to benefit the needy and the less fortunate. Now this commitment is being abandoned, renegotiated or revisited. The consequences for governance have been dramatic. In Ralf Dahrendor's words, "wealth creation, social cohesion and political freedom used to be reinforcing. Now these goals are only achieved at the expense of others."(Dahrendorf, 1995) A deep wedge has been driven between well-being and social equality.

- The internationalization of state activity. Public services are increasingly being delivered by private sector agents as states look to reduce the size of the public sector. Trade agreements facilitate this objective by requiring participating governments to extend national treatment and national presence to foreign-based service corporations. The result is that particularly in laissez-faire economies, economic management is made more difficult than previously because governments are more subject to and reliant on the discipline of financial markets than ever. They now rely on financial markets rather than internally generated savings to supply their investment needs.

- A high employment obligation. People have to work longer, be responsible for their 
education, health and well-being, but, most important of all, accept employment conditions where economic security is no longer the norm. Employers now promote the concept of the work force particularly in the service and industrial economy as contingent with workers having to accept their new status, in the words of James Meadows, Vice President for Human Resources of AT\&T, "as selfemployed vendors who come to this company to sell their skills."(Edmund Andrews, New York Times, February 13, 1996, D1)

If all these changes appear to be definitive measures of many of the changes identified with global free trade, they are not. Footloose corporations are not of recent date. The run-away firm and the use of contracting out by large corporations have been key features of the industrial landscape for much of the twentieth century. Twenty years ago, Barnet and Mueller in their celebrated work, Global Reach warned against the hollowing out of the modern corporation. (1987) Go back farther in time and even in the 1930s the threat had long been recognized. (Marshall, Southard, Taylor, 1936 and 1976)

Today, new technologies have given multinationals and transnationals fresh power and reach that they have not enjoyed previously. What is not immediately apparent is why trade-led adjustment should be so brutal, unmanageable and costly for job-leavers and new entrants to the labour market. If the international market has long functioned like a giant magnet, relentlessly encroaching on and undermining national space and practice, what is novel about the driving force behind global markets and the internationalization of production today?

\section{Three Distinct Features}

\section{a. The destructive cycle of globalization}

The most striking feature of the new global order is the existence, for want of a better word, of a destructive cycle of globalization in terms of full employment practices and objectives. Unemployment levels have doubled in each decade throughout the OECD countries as states have accepted the policy dictates and macro-economic targets of zero inflation targets. (See table, The Unemployment Crisis in the OECD Area 1950-1995) This policy shift is stark and the consequences dramatic as high income and low income states have abandoned their high growth Keynesianisminspired policies of the fifties and sixties in favour of low-growth monetarism of the eighties and nineties as their conditioning framework of state-market relations. Paradoxically even when the export side of the economy is booming, states are left to confront a new reality, namely, that the increase in exports does not generate a sufficient number of new jobs throughout the economy to reduce unemployment levels to what would be regarded as acceptable levels. It is this issue more than any other that needs to be more deeply explored.

If it is a cliché to assert that exports have become the driver of the economy for countries throughout the world and that the export competitive sector now acts as the benchmark for the rest of the economy, this is not the first time that exports have attained such importance. Prior to World War I exports from leading industrial countries were almost as great as they are today hovering around twenty percent of GDP. So it is not a minor structural change in the composition of international 
trade that is necessarily significant at the present time but something more problematic. What is novel from the 70s onwards is that the rate of exports in the economy of advanced capitalist countries has risen by two-thirds.(Bairoch, 1996) Why is the intensification in the continuous growth in imports and exports such an important new development and what light does it shed on the long-term trend inherent in the new global arrangements?

The generally acceptable answer of policy experts used to be that trade was deemed to be an employment enhancing activity. It is useful to remember the principal reasons for it. In a nutshell, a system of mass production is labour-intensive, requiring an army of workers to produce standardized commodities such as a cars, home goods, food products, clothing and electronic goods. The allure of the mass production model was that it held out the promise of mass consumption provided that production (growing output) could be linked to mass consumption (rising wages and incomes).(Armstrong et.al., 1991) When this happened in the late forties and the state was transformed into an active economic agent, wages, profits and production formed a virtuous cycle. The very essence the Fordist system of mass production was to generate new employment possibilities to meet the full employment obligations that governance demanded and the voting public expected.

Enhanced exports were critical to this virtuous policy cycle. When incomes rose sharply and economic growth reached record high levels, it should not be forgotten that even in the heyday of Keynesian-types of policies, exports in the fifties, sixties and seventies grew almost twice as fast as domestic output. Government leaders in the OECD were not indifferent to the benefits of trade liberalization and quickly grasped the powerful logic of a system of mass production for employment creation in the domestic market but also for its trade enhancing potential. (Bhagwati, 1989) The Fordist system of macro-micro management created strong linkages and interdependencies to attract mobile international investment and technology particularly in advanced industrial settings.

The virtuous model of trade liberalization depended on labour-intensive production of standardized commodities, efficiency gains made possible by economies of scale and a strong productivity performance of leading national firms that required continual investment in skill training and the purchase of new equipment. It also held out the promise that consumers were to have cheaper goods while it required that all governments gradually lower tariff barriers. Support for dismantling barriers to trade was not difficult to garner. Labour unions everywhere lined up behind a moderate agenda of trade liberalization. Workers and unions needed little convincing that trade liberalization was 'labour friendly' so long as wages were negotiated by regularized collective bargaining agreements in core industries and not by highly competitive labour markets that made wage increases difficult to obtain. (Drache and Glasbeek, 1992)

In these conditions, structural adjustment was largely state-led. Governments provided assistance and stepped in to reorganize an industry when it failed and workers lost their jobs. In Western Europe and the US many did so due to the higher levels of import competition from tariff-reduction measures. But so long as GDP growth ensured that job creation was strong and that the new hires had a reasonable chance to find good jobs that were better paying than their old places of 
employment, trade liberalization was seen to be compatible with Keynesian full employment objectives. Here too the contrast between then and now is stark.

Dedicated export-led growth is increasingly job-destructive as firms have to cut costs, trim payrolls and shorten the commodity-cycles. Not only do countries have fewer instruments at the ready to address the adjustment costs of markets, but they face quite a different environment in which the international economy impinges more directly than ever on domestic labour markets and wages. Most important is that when countries open their borders despite the costs and regardless of the consequences, it is inevitable that their economies come to rely on global price movements to set social standards as well as work and wages and labour market conventions.(Rodrik, 1998) In the past, the expansion of international trade went hand in hand with an expanded role for the welfare state. Financing of social insurance mechanisms and support for safety nets were not undercut by the pressures of international economic integration.

In his influential book, Has Globalization Gone too Far? (1997) Rodrik challenges the basic argument of most trade economists that there is little impact on wages in the US from international trade and globalization. Rather, his contention is that one of the primary effects of market-driven integration is that trade does indeed affect wages but not in the way economists are able to integrate into the econometric models. What integration changes are the institutional arrangements to an important degree so that "when countries trade with one another many of the long-standing domestic institutions and domestic norms can be eroded through the channel of trade.". Today this is particularly relevant. As the costs of relocating have fallen, keeping wages low is a preferred option of many employers. Employers have much greater bargaining power relative to the workers and so employers can easily substitute foreign workers for domestic workers. At the macro-economic level, the same kinds of dynamics drive a wedge between wealth-creation which relies on the exportindustries and job-creation which is largely occurring in the service and domestic side of the economy.

Traditional economists argue that highly competitive industries ought to create new jobs because countries are exporting more. What should not be ignored is that greater volumes of trade are not generating enough new jobs to replace those that are lost through import competition or the jobs that disappear when domestic firms go off shore. Economists are not certain why this is so but for some there is a strong case to be made that international integration is "aggravating the downward movement in the relative wages of the least-fortunate workers in the economies of the advanced industrial countries." (Rodick, 1997:88) The costs of trade are being borne by the workers themselves because of the basic lack of jobs due to inadequate demand and slow productivity growth in many countries that has kept wages and salaries from rising the way they used to.(Madrick. 1998)

Strikingly, the US experience illustrates the high risk and low returns of the putative global information economy. Even with the massive amount of money invested in computers, peripheral equipment and software, in the US the productivity returns on computer investment have been disappointing. Computers have not reversed the slowdown in US productivity growth. Nobel Laureate Robert Solow defined the paradox several years ago: "You can see the computer everywhere but in the productivity statistics."(Madrick, 1998) 
Despite the massive introduction of new technologies and the dramatic increase in world trade, these miracle-factors, singly or in tandem, have failed to end the global economic crisis. In 1996, world exports grew by 9.6 percent, the second best performance since the boom year of 1976 when trade grew at 11.8 percent. Growth continues to be stalled at between 2, 3 or 4 percent for many OECD countries well below the levels attained in the golden age of capitalism. In Europe, it is estimated that it will not exceed $1.5 \%$ on average compared with $2.5 \%$ at the end of 1995.[IFRI, 1997:96-97]

If anything, the growth in world commerce and output has intensified over the last five decades. Canada and the US, prototypical examples of countries who have embraced export-led growth policies, have seen their imports and exports grow by more than 10.5 percent in 1996. In Canada, the unemployment rate has remained persistently high (roughly twice the US level) and upscale jobcreation in the skilled sections of the labour market has been weak and disappointing. While European countries have better been able to protect their skilled workers and high wage economies, the slowdown in 'good job creation' has much the same origins. German firms, like their counterparts, everywhere are shedding workers and trimming payrolls. It is difficult to find a single example of a major company that has not cut its workforce by twenty percent and upwards since 1989.

Here in a nutshell then is the core issue in the world economy today: record-breaking levels of international commerce have been achieved at the expense of a strong national recovery and sustained growth rates. In short, global boom-national bust has become a structural feature of the relentless drive to open markets at any price. Record high unemployment throughout the industrial world is one of the consequences. In the European Union more than 20 million people are out of work or underemployed. (Financial Times, July 10, 1998) In the US the figure is under 5 percent but the number of working poor and the presence of wage polarization have reached levels not seen since the 1930s. ${ }^{4}$ The growing split between the world's most successful economy and the high unemployment economies of Western Europe is now wider than it has ever been. Even US productivity growth remains flat by historic standards averaging about 1 percent a year since the 1970s, compared with an average of 2.3 percent annually during the previous century. (Lester, 1998) Many experts now believe that Americans cannot expect to see an improvement in their living standards even if their unemployment numbers are the best in the world.

\section{b. The new benchmark of governance}

A second dramatic change is that triumphant liberalism in its many reiterations has become the benchmark of good governance. The Keynesian state with its universal social programs is under revision, attack and reorganization and the leaner, meaner state inspired by powerful pro-market

${ }^{4}$. The growth of the union free workplace, the appreciation of the dollar, cheap imports and lower medical insurance costs all have combined to contribute to stable US labour costs and low employment. In its recent 1997 report, the OECD rejects the idea that the US is heading to a new era of low unemployment and low prices. Rather it sees these factors as transitory and that job creation depends on 'highly asynchronous business cycle'. 
arguments is back. If all countries are increasingly inter-related in one competitive marketplace, there is no another reality to confront. Many of the features wrongly attributed to the globalization revolution are in fact driven by the US agenda. It is the norm setter of the trade world. Its agenda and vision of how trade and markets ought to be organized defines the standard for success where gaining a larger share of the global marketplace defines what it means to be a winner. Certainly the US state has gone further in reinventing itself than has any other comparable jurisdiction - it has made its labour market the most competitive of any nation; reduced employment security to the legal minimum; cut taxes for the middle class and upper income groups; reduced social spending and social programs; and promoted strong entrepreneurial activity that lets companies start small and grow quickly.(OECD, 1997)

For a remarkable article articulating this vision of the new world order, read Richard Rosecrance's "The Rise of the Virtual State" in Foreign Affairs 1996. His principle article of faith is that as territory is becoming passé, the nation-state is "becoming a tighter, more vigorous unit capable of sustaining the pressures of worldwide competition." If governments are to be part of this new civilization, they have to learn that governing the economic culture of the world market is their primary goal. Hence the public policy agenda of each country has to be broadened to include new international agreements on competition policy and corporate behaviour. Indeed countries have to be ready to sign legally binding agreements which, in his words, "have to reach behind national borders." This powerfully energetic legal instrument has an imposing global agenda with a transformative vision of the way society is to be organized. It proposes new rules of the game for private and public actors, a rapport de force between the state and market and has a plan of wealth creation that relies on new private forms of activity and a reorganized firm compatible with the new international order. More than anything else, the centrepiece of change is the emergence of a refashioned state with its own forms and practices. (Yergin, 1998)

In the postwar world, the state structure of government rested on three identifiable principles: a Bevridge-inspired social policy, a Keynesian-based macro economic management approach and a Fordist model of employment relations originally designed for the mass production industries. The new pillars of the modern state are striking different from its Keynesian antecedents. I call it the Kmart state, emblematic of the new work world of the casual, part-time, low wage non-unionized service sector. (Drache, 1996) With its system of commerce dependent on standardized goods that are assembled anywhere and sold at the 'lowest price possible'; this fiercely competitive retail sector guarantees the consumer a culture of mass consumption but one which less and less is rooted in domestic industries. In this context, it is easy to see why the US has gone farther in de-territorializing its national system of production followed by Australia, Canada and the UK. The Kmart system of mass consumption requires delocalization as much as possible from high cost producers located particularly in the advanced sectors of the world. For the US, sharing a common border with Mexico gives it special access to the low-cost maquiladoras for many US industries while to the north US producers depend on Canadian resources to keep costs under control. US industry needs a hub-spoke relationship where low cost labour zones can be incorporated into the structure of production. (Eden, 1994) 
In terms of labour market practices the idea is that employees do not need a support system or extensive safety nets. Instead in a highly competitive open economy, the price of goods depends on wages being set by the market rather than through collective bargaining agreements. In these circumstances, workers are forced to compete against each other to keep their jobs and their industries profitable. It makes workers more easily substitutable for each other through outsourcing, trade and foreign investment.(Rodrik, 1998) As managers of the system, countries too are forced to become price takers. In the race to win new markets, cost cutting strategies become a critical component of any corporate or national strategy.(Rifkin, 1996)

In theory this is supposed to occur through a country's comparative advantage where each state must use its revealed economic strengths to gain larger market share from the competition. In practice, with so much of restructuring driven by short-term effects from currency fluctuations, increasingly it requires public authority to have a focussed set of state policies and practices to broaden investment rights and find new ways to support domestic manufacturers and exporters. In the US, it takes a particular regulatory form not of intervention but of protecting the rights of individuals (particularly children) as consumers or citizens. This is a legitimate area where the US government can reassert itself at home and protect its citizens as every government must. ${ }^{5}$ In trade matters the US practice as defined by the Congressional arm of government increasingly diverges from the free trade model. Instead it wants to impose trade sanctions on any country that engages in activities that could be considered "hostile to US business interests" or failures to comply with other US norms and expectations. In 1997 the US Congress signed 23 sanctions measures. (Financial Times, Mark Suzman, June 5 1998)

Reliance on the state in preference to the market is very much in evidence in European integration. The European union was founded on the reality that Europe needed a larger state, not a smaller one. But Europe suffers a dispersal of authority to nations and regions and has not been able to speak with a single voice in Brussels on social policy let alone a more demanding strategic issue such as trade policy. Nonetheless monetary union is an embryonic economic government even if the delineation of the respective roles of Union and national governments is very unclear because member states are not prepared to give up state aids and other national instruments of trade-enhancement that would empower capital markets at the expense of social stability. So it is likely that Europe will do more for itself with the new EMU area having a gross domestic product nearly 80 percent of the US and 50 percent larger than Japan.

With governance redefined by the norms of self-interest, the economic functions of 'the trading state' are radically different from those of the welfare state. The state's main role has become that of a negotiating entity internally as well as externally. In the words of Rosecrance, " it depends as much or more on obtaining economic access [abroad] as it does on economic control at home."

${ }^{5}$ The Clinton administration has been quite active on the regulatory front from everything from air bags in cars to limiting sex and violence on the Internet as well as possible tobacco legislation. Despite opposition to limiting consumer rights, it has shifted the terms of the debate about big government by recasting it as a question of protecting children. 
(Rosecrance, 1996, 52) This is why it is a testing time for all national systems of management. Countries that plan and manage their economies are likely to be better positioned than those that do not.

\section{c. Divergence is as important as convergence}

Finally, contrary to what many experts predicted (that trade and investment flows would be the great equalizer,) there is no dramatic case of convergence in government policy and practice, no singleminded response to global markets by public authority. State spending has increased in all countries. Even in the US and other Anglo-Saxon jurisdictions the state remains the most important institution in the economy. If a smaller state is equated with paying less taxes, no idea is more mistaken. Nor is there much concrete evidence that open finance and trade requires smaller government. State spending has continued to increase throughout all G-7 countries. (See table, Labour Productivity and Labour Costs in the Euro-zone, 1997)

Significantly, the most important measure that captures the evolving role of the state in modern times is the role of the state as tax collector. Here the evidence is unmistakable. In the aggregate, the tax burden measured as a percentage of GDP has increased in all leading jurisdictions including the US. What tax cuts there were for high income earners occurred in the eighties. Since then the burden of taxation has climbed for a particular reason. Governments everywhere need to broaden their tax base and they have been forced to impose new taxes and change the tax mix. In many Anglo-American countries authorities are increasing both personal and consumer taxes while de-taxing corporations and high income earners. By contrast, in the social market economies, tax cuts do not provide a particularly effective way to either create jobs or boost demand and these economies remain high tax as well as high wage jurisdictions. Japan is in a category of its own and while it is perceived as a high taxation country, this is not the case. It has a very narrow tax base compared with other G-7 countries because the proportion of revenues collected through consumer taxes is low but corporate taxes

\section{Trade Barriers are Also on the Rise - Another Example of the Divergent Response to Integration}

Countries too are building new barriers to trade as fast as the old ones are dismantled. The European Commission has sought to win trade protection by imposing punitive import duties on such diverse goods as microchips, office equipment, televisions , machinery, footwear and minerals as well as cotton textiles and clothes. By the end of 1996 there were 143 antidumping measures in force and these are at the direction of the European Commission. The US has 298 anti-dumping measures in effect and the numbers continue to increase despite the rhectoric of competitivness and the need to take the state out of trade.

Source: WTO Report, Commission Annual Report to European Parliament, Financial Times, July 28, 1998. 
are high. Small companies are taxed very lightly that may explain its highly innovative business and research culture. In any event, taxation remains society's most important collective resource for all states. No state (other than the US) has succeeded in moving very far down the de-taxation policy option despite predictions to the contrary. There is no convergence in sight on the tax question. National differences remain as great today as in the 80s with France and Germany at the high end and the US at the low for corporations and the rich.(Nickell, 1977)

Nor has the putative move to the smaller state eradicated to any important degree the very substantial differences in state spending, governance, taxation, social policy and labour market practice. Divergence as reflected by size of the public sector and the amount of public spending on health, education, social services and labour market adjustment as a percentage of GDP has remained strong and pronounced within the OECD countries. These counter movements are very significant with respect to state reliance on subsidies that have increased and not diminished in recent times; the continued growth of the public sector in most jurisdictions; the importance of social policy as a proportion of public spending; the large number of state enterprises that most advanced jurisdictions have not been privatized; the singular importance of health expenditures as the largest budgetary item for most countries and the widespread support for unemployment assistance regimes and benefits. (Drache and Sullivan, 1998) Since 1990 the public sector in Western Europe has grown constantly despite perception to the contrary. (Economist, 1997) This stands in sharp contrast to public sector employment levels in the US and Canada that have seen thousands of jobs lost. With respect to R\& D expenditures, forty percent of research funds in Germany depend on the state while

in Canada and the US the state has been withdrawing support and public money from this crucial area of endeavor.

Of even more significance is the fact that there is very little empirical evidence that lowering taxes and labour costs has created a level playing field within OECD countries, the very jurisdictions which have supported zero-inflation and zero-deficit targets. Fifteen years of monetary reforms have failed in this important respect despite the concerted efforts of national and international authorities to achieve this goal. Wage-setting and social security systems continue to be anchored in their national structures. (Carnoy and Castells,1997) One crucial measure is that high wage, high skill economies of France, Italy, Germany and Belgium for instance, have not seen their manufacturing wages converge to dramatically lower US or UK levels. Despite what economists have termed 'deep' integration measures on both sides of the Atlantic and despite powerful pressures of global competitiveness, economies respond in sharply different ways to powerful internal and external measures. When the numbers are examined, it is hard to believe after forty years of European union that national differences in terms of productivity, compensation and unemployment remain so pronounced. (See table, Total Costs of Labour in the Manufacturing Industry in Various Countries 1995 ) While this is not a new finding by any means, it has gained new significance as Europeans considers the benefits of monetary union.

Using Germany as the benchmark against which to measure other member country's performance in this critical area, a recent research report found that only three countries came within ten percentage points of the Western German level. Ireland, Eastern Germany and Spain are between 60 and 70 
percent while Portugal is at 34.5 percent. (Financial Times July 7, 1998) The issue here is that some might assume that with monetary union will there be a need for 'the same wage for the same work?' In theory there is a case but it is doubtful that there will be any moves towards a Europeanization of wage formation. As the author of this study warns, its immediate impact would be to increase unemployment for countries where labour and productivity costs lag behind German levels. If divergence in productivity levels makes certain that costs of social security must be different, it makes no sense to see European integration as converging towards a narrow set of monetary objectives. Centralizing monetary policy is not going to change the fundamental reality that many other aspects of economic management will remain the responsibility of individual member states.

Factually, it makes no sense to speak of wage compression as a precondition for further integration. In many countries today competitiveness is not related inversely to the hourly wage rate as orthodox economics dictates. With nominal wages and inflation stable throughout most of the industrial world future income and consumption growth will depend increasingly on rising levels of employment which, in turn, depends on a strong recovery and real income growth. Countries that have high wages are not necessarily disadvantaged by competition. The US and the UK - low wage jurisdictions in many industries with a 30 percent wage difference in their favour - are running massive trade deficits with Germany, France, Italy and Japan their high wage partners. Evidently there are many other factors that explain this puzzle. What seems clear is that final export price continues to be set by more than the hourly labour cost.

What stands out is that since 1980, across the industrial world, wage differentials between countries have not dramatically been reduced in response to trade liberalization measures. The single exception is the UK where the average industrial wage has dropped by almost forty percent. By contrast, Japan, Germany, France, Belgium, Holland and Italy continue to be high wage/high skill economies. At the other end of the scale are the laissez-faire market economies where wage costs have declined sharply particularly for those in the middle of the wage scale and at the lower end. Recent data illustrates just how deep the divide is. For industrial workers from former social democratic societies such as France, Italy and Germany, the average total hourly wage bill ranges from \$32.00 US for Germany, in 1997, 54 percent higher than the US (\$17.19) to $\$ 18.53$ for France $\$ 15.29$ for Italy to $\$ 14.01$ for the UK. Most of that difference is accounted for by employer contributions. According to Roach, compulsory benefits and social insurance programs accounted for 45 percent of total hourly compensation in social market settings while in the US the figure was a mere 28 percent. In Germany, social contract accounted for two-thirds of the disparity between US and German wage levels in 1996. ( Stephen Roach, Financial Times, May 27 1998) 
Institutional Diversity, Market Performance and Globalization

\begin{tabular}{|c|c|c|c|c|c|c|}
\hline & $\begin{array}{l}\text { Jobless } \\
\text { Rate }\end{array}$ & $\begin{array}{l}\text { Tax } \\
\text { Burden }\end{array}$ & $\begin{array}{l}\text { Social } \\
\text { Policy }\end{array}$ & $\begin{array}{l}\text { Public Sector } \\
\text { Employ }\end{array}$ & $\begin{array}{l}\text { State } \\
\text { Spending }\end{array}$ & $\begin{array}{l}\text { Deficit } \\
\% \text { GDP }\end{array}$ \\
\hline US & low & low & low & reduced & lowest & $\begin{array}{l}\text { surplus and } \\
\text { will } \\
\text { continue } \\
\text { into next } \\
\text { century }\end{array}$ \\
\hline Canada & $\begin{array}{l}\text { twice US } \\
\text { levels and } \\
\text { rising }\end{array}$ & $\begin{array}{l}\text { roughly } \\
\text { comparable; } \\
\text { but } \\
\text { significant } \\
\text { consumer } \\
\text { taxes }\end{array}$ & $\begin{array}{l}\text { reduced by } \\
\text { historical } \\
\text { standards; } \\
\text { still } \\
\text { transfers to } \\
\text { people } \\
\text { critical }\end{array}$ & $\begin{array}{l}\text { reduced } \\
\text { sharply at } \\
\text { federal and } \\
\text { provincial } \\
\text { levels }\end{array}$ & $\begin{array}{l}\text { higher than } \\
\text { US levels }\end{array}$ & $\begin{array}{l}\text { Surplus of } \\
\$ 8-10 \\
\text { billion } \\
1998 ; \\
\text { further } \\
\text { surpluses } \\
\text { forecast }\end{array}$ \\
\hline France & $\begin{array}{l}\text { double } \\
\text { digit }\end{array}$ & $\begin{array}{l}\text { employer } \\
\text { contribution } \\
\text { higher than } \\
\text { US levels }\end{array}$ & $\begin{array}{l}\text { no } \\
\text { significant } \\
\text { drift to US } \\
\text { levels but } \\
\text { reductions } \\
\text { in } \\
\text { coverage }\end{array}$ & $\begin{array}{l}\text { growth of } \\
\text { public } \\
\text { sector } \\
\text { significant } \\
\text { since } 1990\end{array}$ & $\begin{array}{l}\text { almost } \\
\text { double US } \\
\text { levels and } \\
\text { rising }\end{array}$ & $\begin{array}{l}\text { reductions } \\
\text { but barely } \\
\text { under } \\
\text { control and } \\
\text { likely to } \\
\text { rise }\end{array}$ \\
\hline Germany & $\begin{array}{l}\text { double } \\
\text { digit but } \\
\text { declining }\end{array}$ & high & $\begin{array}{l}\text { major } \\
\text { benefits in } \\
\text { place but } \\
\text { reforms } \\
\text { immanent }\end{array}$ & $\begin{array}{l}\text { growth of } \\
\text { public } \\
\text { sector }\end{array}$ & $\begin{array}{l}\text { one of the } \\
\text { highest } \\
\text { amongst } \\
\text { countries }\end{array}$ & $\begin{array}{l}\text { difficult to } \\
\text { keep to } 3 \\
\%\end{array}$ \\
\hline UK & $\begin{array}{l}\text { double } \\
\text { digit }\end{array}$ & falling & sharply cut & $\begin{array}{l}\text { massive } \\
\text { reductions }\end{array}$ & $\begin{array}{l}\text { rising after } \\
\text { sharp } \\
\text { decline }\end{array}$ & $\begin{array}{l}\text { low by } \\
\text { OECD } \\
\text { standards }\end{array}$ \\
\hline Japan & $\begin{array}{l}\text { still low } \\
\text { by } \\
\text { Western } \\
\text { European } \\
\text { standards } \\
\text { but high } \\
\text { by } \\
\text { Japanese }\end{array}$ & $\begin{array}{l}\text { high taxation } \\
\text { regime }\end{array}$ & $\begin{array}{l}\text { massive } \\
\text { spending }\end{array}$ & $\begin{array}{l}\text { modest } \\
\text { state } \\
\text { reform }\end{array}$ & $\begin{array}{l}\text { major } \\
\text { programs } \\
\text { continue }\end{array}$ & growing \\
\hline
\end{tabular}


In sharp contrast to what neo-classical theory teaches markets do not rule everything. Institutional forms and practices of all kinds continue to make a critical difference. They protect the social dimension of society even when countries are more trade dependent than ever. In this respect Germany is ahead of laissez-faire economies in providing social benefits and ensuring social fairness. A consensual society such as Germany has not abandoned its own model of corporate governance. Co-determination gives an estimated 5.2 million employees in more than 700 companies with more than 2,000 employees near parity on in their supervisory boards. (Dore, 1996) The co-determination model has been adopted by more firms since 1990 and one of the reasons that gives particularly export-oriented manufacturers an advantage. It fosters a culture of co-operation in which companies invest strongly in human capital as well as make large scale investment in plant and equipment. One result is that Germany continues to have a very large industrial sector employing 37.5 percent of the workforce compared to Japan's 33.3 percent, the UK's 27.4 percent and 23.8 percent in the US in 1966. (Peter Norman, Financial Times, June 1 1998) In this as in other areas, state policy is as important as sheer market power.

But in other ways, there can be little doubt that German employer's associations want the rules and terms of Germany's social contract relaxed and the regulations changed along the lines of more flexible labour markets of the UK or the US. This is unlikely to happen quickly or easily. Germany's system of collective bargaining has made it a country of high productivity with a strong currency and high wages. (Streeck, 1996) For the past decade the multi-skilled German worker has turned in an impressive performance. While German wages are seen to be high comparatively, the view on the ground is quite different. Since 1990, real hourly wages have trailed hourly productivity. In 1997 , wages grew by 1.5 percent while productivity surged by 3.7 percent. The trend in Germany is no different from other countries as work in the high wage sector declines as firms cut the size of their workforce. Since 1990 job growth in the industrial side of the economy has been negative in five out of seven years. Evidently as far as labour market adjustment is concerned European economies face intense pressures to modify their social market practices as the European Union's monetary day of reckoning approaches.

Clearly, the social market economies of Western Europe have not been spared; the system of interstate relations has been radically altered from even a decade ago. Some of this is reflected in the kinds of economic statistics that capture the divergence-convergence criteria, but many are not, for good reason. A different kind of conceptual-analytic tool is needed. This is because all countries, regions, cities and neighbourhoods are living in the eye of a hurricane in which systemic change is the order of the day. A complex regime change is taking place nationally and internationally throughout the industrial world that is redefining the division of powers within each country even more than the relations between countries.

\section{The Old and New Model of the International Economy in National Life}

From this perspective the ascendency of the globalization narrative is recognition of something more dramatic. It is a kind of Braudelian-Innisian epoch-making moment in which fundaments other than market forces are challenging state authority and practice. (Helleiner, 1997)Space and time as well 
as hierarchy and state forms are being compressed, deepened, strengthened, stretched and reconfigured globally and locally by powerful new technologies and social forces. It is the potent mixture of these gale-like conditions and powerful counter-movements from below that is redefining governance and causing new state forms to emerge. (Innis, 1995;Braudel, 1980)

At the centre of this change is a more fundamental realignment that has major consequences for public policy. Public policy formation had an implicit, if not explicit, model of the place of the international economy in national life. Conceptually it used to be envisaged as being at arm's length from the nation-state for a principal reason. The nation-state was seen as a enormous conduit something like a giant funel through which modern exchange transactions entered the national economy via the nation-state. Countries were 'tied' to the 'market beyond the state' by trade, immigration, capital and cultural movements - the umbilical cords of interdependency. The international economy stood outside individual countries and modern economic transactions were funnelled through the national government down to the neighbourhood levels. This was relatively easy to control when there were tariffs, customs duties and other regulatory measures that required state surveillance. But there was another dimension still. Keynesian kinds of policies were designed to enhance national governance by erecting a regulatory firewall around the national economy. Modern governance was born with this idea -- part fact and part fiction -- that governments had to protect society from the twin dangers of economic uncertainity and the chronic instability of the global business cycle.

In idealized terms, life inside the nation-state was seen to be well-defined, ordered and hierarchical. Power was centralized in the hands of national government as it controlled finance, money, taxation, social policy, employment, the judiciary and the army. There was also a well-defined division of powers that assigned national governments their financial and moral authority over regions, cities and neighbourhoods, families and social classes. So what is dissimilar today about this picture of a world that once was held to be unchanging?

The answer is that there has been a fundamental reordering in the interface between states and markets internally and externally. There are fewer state-maintained buffers to protect the 'orderly life' inside the fictional skin of the nation-state than any time in the recent past. This kind of 'levelling up as well as down' has been at the centre of the battle between the government and the marketplace. (Yergin and Stanislav, 1998) There has been a wholesale shift towards new state practices, powerful integrative trade blocs, lean production practices and competitive labour markets. The same factors have also strengthened the city as a regulatory site and a place of reaction and resistance to these globalizing trends. Social movements like Greenpeace have emerged as counter-movements of identity and resistance to the market beyond the state. ( see figure, The Old Model of the World Economy and Globalization in the New Era) Even if it is the case that some economies are relying less on market signals and are maintaining social stability by modernizing existing institutional arrangements and protecting their social capital, at a more fundamental level all countries have no choice but to address the new institutional realities and constraints of structural integration.

Social market or not, globalization has changed the public agenda because insecurity for individuals and nations has been heightened as elites have attempted to impose uniformity of condition through 
new trade rules and practices in the hope of building a level playing field that denies the specificity of difference. Consequentially this seed change in public policy-making has strengthened both the attachment of people everywhere to their national economy as well as reinforcing a stronger sense of local and regional identity during the period when national governance has been under pressure to conform and adapt. It is the paradox of change in a global era that these powerful economic pressures have promoted a stronger 'sense of civic engagement', in Robert Putnam's words, as people have sought to build networks and connections that define the new sense of civic space.(Putnam, 1993) These dense social networks need to be mapped in order to understand the divergent practices and conventions that support powerful counter-movements from below. The sizeable not-for-profit sector can act as a buffer against global competitive pressures. It is likely that reliance on the non-traded public goods sector that cannot be bought such as public freedoms, human rights, government transparency and public accountability will increase as the World Bank has recently stressed in its 1998 World Bank Report. If this is so, it can never be assumed that in the struggle between the local and the global that markets have gained the upper hand. Instead there is every likelihood of the public domain is on a collision course with the private sector. (Keil, 1998) There is a lot of room for tension and conflict between the diversity of locally negotiated arrangements and commitments that require the social capacity of government to be an effective manager of market failure and the social distortions flowing from enlarged markets and global competitive pressures

\section{A Final Word}

Elites everywhere have built links between their country's economy and the rest of the world for the past five hundred years. Not surprisingly, this gave rise to such transnational social movements as the Jesuits, Free masons, the Rhodes/Milner group in the British empire as well as American business organizations like the Chamber of Commerce and powerful lobby groups like Foreign Affairs supported by the Carnegie Foundation and the Rockefeller interests -- just like now -- which worked to ensure that capital expanded beyond the nation-state. (Schorr) For these elites, power was never exclusively state-centred even when the nation-state's power was unrivalled by international forces.

Nor is it unexpectedly that, even in the heyday of nationalism, people had their sights fixed beyond their bounded worlds of the nation-state because the international realm had created its own imaginary community of interest. By the time of World War I, internationalism had come of age, energized and politicized by the Pacificist movement. (Sassoon, 1996)Others followed this movement's clear-headed example - the suffragette battlers for international equality, the Fourth International with its hopes and failures, the single-mindedness of the anti-colonial movements of the $30 \mathrm{~s}$ and $40 \mathrm{~s}$ as well as the spirited nuclear disarmament marchers and militancy of the 'development decade' of the sixties. It is not difficult to see the larger tableau in these disparate episodes, namely that popular resistance to crude economic global determinism has been one of the enduring themes of twentieth century political thought and social activism. This too gives grounds to reflect upon the prospect and possibility of promoting co-operation and developing effective public policy instruments by broadening and deepening the capacity for democratic governance. 
Free trade regimes in the $19^{\text {th }}$ century and the interwar $20^{\text {th }}$ century as well as now have been high risk strategies with terribly complex political arrangements, requiring constant international negotiations to put in place ever more complicated kinds of international agreements. Yet, they inevitably collapse because without any redistributive mechanism the material benefits turn out to be so few for countries at such different stages of development. The current grand design for a world of open markets and unparalleled access faces the same challenge of survival. If history teaches any lesson it is that free trade regimes are not sustainable for very long. The principal reason is that the political market for social protection -- jobs and a higher standard of living by more traditional instruments of all kinds -promises more immediate rewards for most governments and peoples than the abstract tenents of laissez-faire free trade.

If this is so, we should be moderate optimists. Can one intelligently sort out the long-term irreversible aspects of globalization from the quest for less state, less taxes, less social policy and competitive labour markets? Of course.

The basic lesson is that the global economy has always been the great seducer of the national interest capable of redirecting national economies for extraordinary short-term financial gain followed by jolting social and political crashes. The first task is to begin to explain these things clearly and to understand why globalization has gone too far, that it is a terribly fragile order and that social life is not enveloped by the internationalization of trade, production and finance in anywhere near absolute terms. Pax civitas orbis.

In edging toward a deeply polarized world of social disorder and economic uncertainty, the nationstate -- as imperfect as it is -- remains the key arena of governance despite the power of global financial markets to influence policy-making everywhere. The fact is that triumphant liberalism is not a universal program for all. It will try to become the dominant narrative; it will come close to achieving its goal, but in the end, it will not succeed for a very important reason. Market structures and forces remain highly specific to local/national conditions. As countries respond to the new competitive circumstances, they will increasingly turn to their own institutional arrangements and the public domains to maintain political stability and economic growth in the face of significantly expanded markets and declining regulatory measures. 
Total Costs of Labour in the Manufacturing Industry in Various Countries 1995

\begin{tabular}{|l|l|l|l|l|}
\hline Country & $\begin{array}{l}\text { Indices based on } \\
\text { data in common } \\
\text { currency; } \\
\text { Germany=100 }\end{array}$ & Remuneration & $\begin{array}{l}\text { Non-wage } \\
\text { labour costs }\end{array}$ & $\begin{array}{l}\text { \% of social } \\
\text { security and } \\
\text { income tax in } \\
\text { compulsory } \\
\text { deductions }\end{array}$ \\
\hline Germany & 100 & 55 & 45 & 39 \\
\hline Japan & 75 & 59 & 41 & 34 \\
\hline France & 61 & 54 & 46 & 47 \\
\hline USA & 55 & 71 & 29 & 29 \\
\hline Italy & 52 & 50 & 50 & 37 \\
\hline UK & 45 & 73 & 27 & 18 \\
\hline
\end{tabular}

Source: Institut der Deutschen Wirtschaft. IW-Trends: IMF, Government Finance Statistics; OECD, Statistics concerning public revenue in the members states of the OECD; Confederation of Swedish Employers; national data. Adapted from Albert, 1997. 
Labour Productivity and Labour Costs in the Euro-zone, 1997

\begin{tabular}{|l|l|l|l|}
\hline Country & Productivity $(\%)$ & Costs $(\%)$ & Jobless Rate (\%) \\
\hline Austria & 90.9 & 89.5 & 4.4 \\
\hline Belgium & 97.6 & 107.6 & 9.2 \\
\hline Finland & 81.4 & 93.8 & 14 \\
\hline France & 95.3 & 95.6 & 12.4 \\
\hline Germany & 92.9 & 95.3 & 9.7 \\
\hline \multicolumn{1}{|c|}{ west } & 100 & 100 & 8.3 \\
\hline east & 60.4 & 74.4 & 15.7 \\
\hline Ireland & 69.5 & 71.8 & 10.2 \\
\hline Italy & 85.3 & 79.9 & 12.1 \\
\hline Netherlands & 85.4 & 94.4 & 5.2 \\
\hline Portugal & 34.5 & 37.4 & 6.8 \\
\hline Spain & 62 & 66.9 & 20.8 \\
\hline UK* & 71.7 & 68 & 7.1 \\
\hline $\begin{array}{l}* \\
\text { using actual central }\end{array}$ & $\begin{array}{l}\text { Based on nominal GDP } \\
\text { per person employed as } \\
\% \text { of western Germany. }\end{array}$ & $\begin{array}{l}\text { Based on gross } \\
\text { compensation per } \\
\text { Germany. }\end{array}$ & $\begin{array}{l}\text { Based on standardized OECD } \\
\text { rates with Kiel Institute } \\
\text { calculations for eastern and } \\
\text { western Germany. }\end{array}$ \\
\hline
\end{tabular}

Source: Kiel Institute of World Economics, in Financial Times July 7, 1998 


\section{The Old Model of the World Economy}

\section{International Economy}

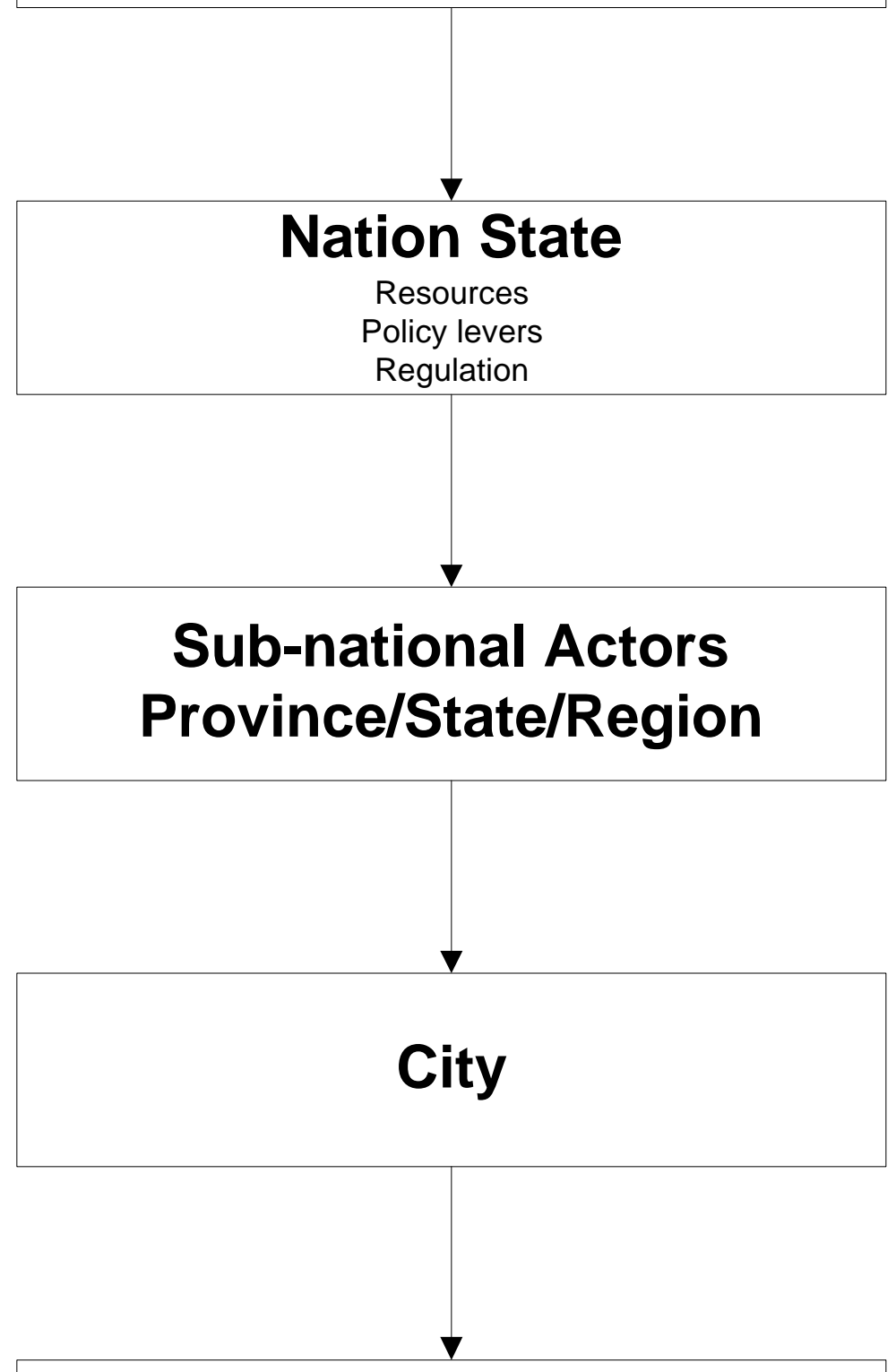

Neighbourhood 


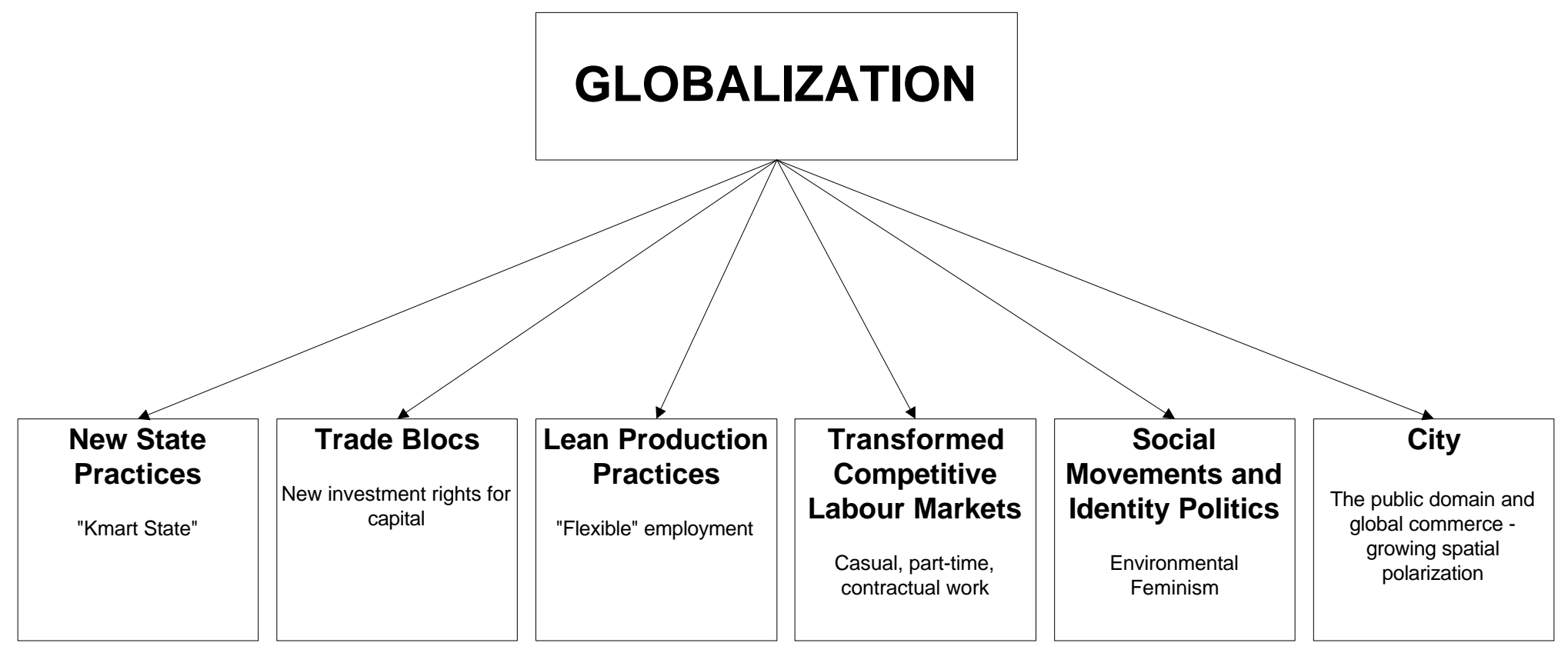

The re-ordering of the interface between states and markets internally and externally.

The world market bombards the city and neighbourhoods with great intensity. 


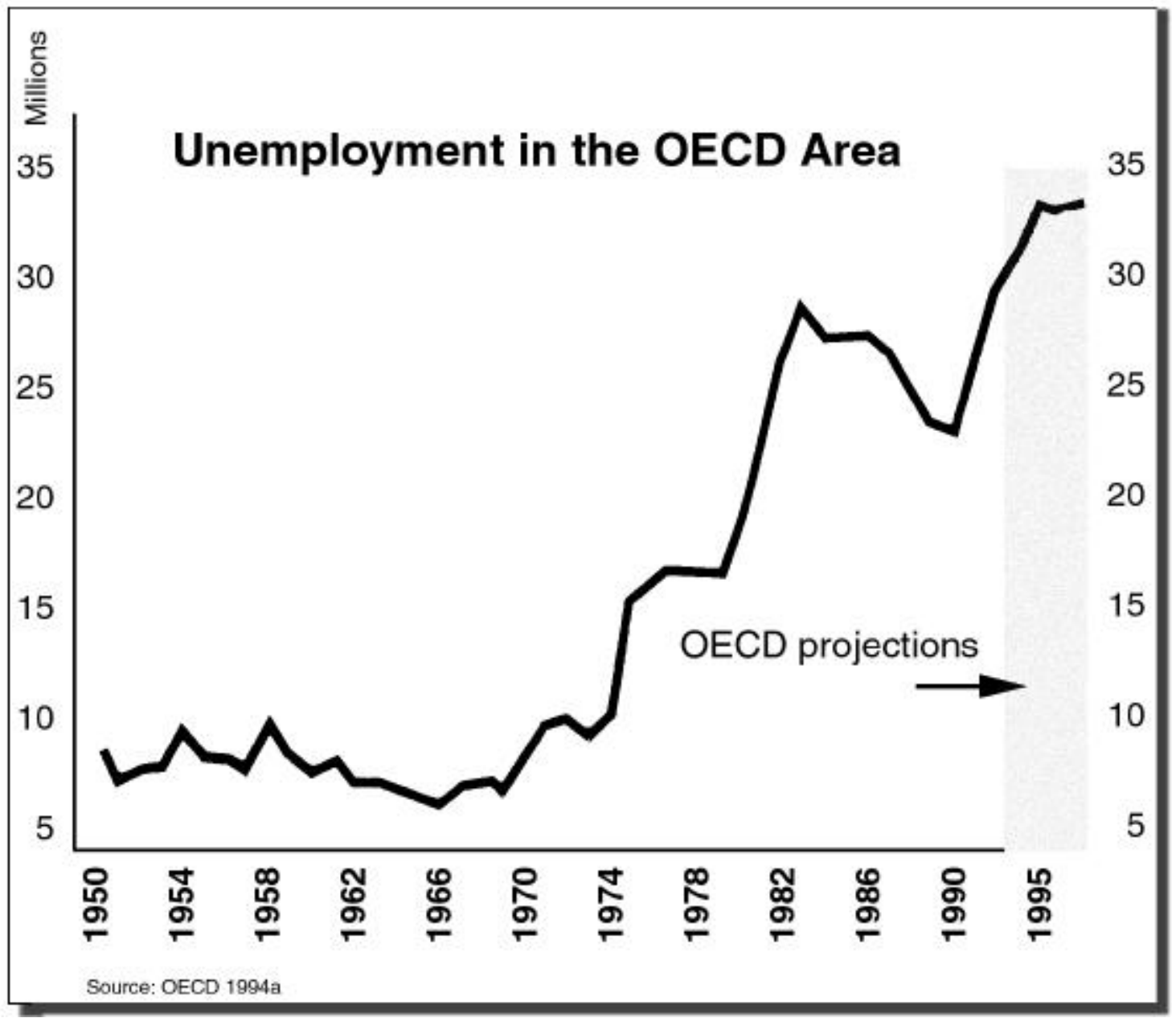


Bibliography

Adda, Jacques (1996). La Mondialisation de l'economie: 1. Genese 2. Problemes. Paris, La Decouverte.

Albert, Michel (1997). The Future of Continental Socio-Economic Models. MPIfG Working Paper 97/6, Max-Planck-Institut fur Gesellschaftsforsh, June.

Albert, Michel (1991). Capitalisme Contre Capitalisme. Paris, Seuil.

Armstrong, Philip,Andrew Glyn, et al. (1991). Capitalism Since 1945. London, Basil Blackwell.

Bairoch, Paul (1996). Globalization Myths and Realities: One Century of External Trade and Foreign Investment. States Against Markets The Limits of Globalization. Robert Boyer and Daniel Drache. London, Routledge.

Barnet, Richard and Ronald Mueller (1987). Global Reach: The Power of the Multinational Corporation. New York, Simon and Schuster.

Barnet, Richard and John Cavanagh (1994). Global Dreams Imperial Corporations and the New World Order. New York, Simon \& Schuster.

Bergsten, Fred (1996). “Globalizing Free Trade.” Foreign Affairs 75:3(May/June): 105-120.

Bhagwati, Jagdish (1989). Protectionism. Cambridge, Mass., MIT Press.

Blank, Stephen (1994). "The United States On the Eve of the 21 st Century." Global Business Policy Council no.7(April): 1994.

Bowles, Paul and Barnet Wagman (1998). "Globalization and the Welfare State Four Hypothesis and Some Empircal Evidence.” Eastern Economic Journal 23:3(Summer): 317-336.

Boyer, Robert and Daniel Drache, Ed. (1996). States Against Markets: The Limits of Globalization. London/New York, Routledge.

Boyer, Robert (1996a). "La Globalisation: Mythes et Realities.” CEPREMAP/CNRS(juillet): Paris. Braudel, Fernand (1980). On History. Chicago, University of Chicago Press.

Carnoy, Martin and Manuel Castells (1997). Sustainable Flexibility A Prospective Study on Work, Family and Society in an Information Age. Paris, OECD.

Cable, Vincent (1995). "The Diminished Nation-State: A Study in the Loss of Economic Power." Deadalus 124/2: 23-53. 
Cable, Vincent (1996). "The New Trade Agenda: Universal Rules Amid Cultural Diversity." International Affairs 72:2(April): 227-246.

Carr, E.H. (1981 (original edition, 1939)). The Twenty Years' Crisis 1919-1939. London, Macmillan.

Colin, Crouch and Wolfgang Streeck, Eds. (1997). Political Economy of Modern Capitalism. London, Sage Publications.

Dahrendorf, Ralf (1995). “A Precarious Balance: Economic Opportunity, Civil Society and Political Liberty." The Responsive Community(Summer): 13-38.

Dore, Ronald (1996). "Unions Between Class and Enterprise." Industrielle Beziehungen 3:2(Jahrgang): 154-172.

Drache, Daniel and Terrance Sullivan, Ed. (1998). Public Success, Private Failure. Market Limits to Health Care Reform. London, Routledge.

Drache, Daniel (1997). Governance and Public Policy in a Global Economy. A Report on Jobs and Investments Strategies in Canada, Robarts Centre for Canadian Studies.

Drache, Daniel (1996). "From Keynes to Kmart: Competitiveness in a Global Age". In Robert Boyer and Daniel Drache, Ed. States Against Markets: The Limits of Globalization. London/New York, Routledge.

Drache, Daniel and Harry Glazebeek (1992). The Changing Workplace. Toronto, Lorimer.

Economist (1997) The State Against the Market, Special Report September 20.

Eden, Lorraine, Ed.(1994). Multinationals in North America. Calgary, University of Calgary Press.

Esping-Andersen, Gosta (1997). Welfare States at the End of the Century. Family, Market, Community: Social Policy Studies No.21. OECD. Paris, OECD.

Group of Lisbon (1995). Limits to Competition. Cambridge, Mass., The MIT Press.

Greider, William (1996). One World, Ready or Not The Manic Logic of Global Capitalism. New York, Simon \& Schuster.

Hall, Peter, Ed. (1989). The Political Power of Economic Ideas: Keynesianism across Nations. Princeton, Princeton University Press.

Helleiner, Eric (1997). Braudelian reflections on economic globalization: the historian as pioneer. Innovation and Transformation in International Studies. Stephen Gill and James Mittleman. 
Cambridge, University of Cambridge Press.

Hirst, Paul and Grahame Thompson (1996). Globalization in Question. London, Polity Press.

Hobsbawm, Eric (1994). Age of Extremes The Short Twentieth Century 1914-1991. London, Michael Joseph.

Innis, Harold (1995). Staples, Markets and Cultural Change. Selected Essays. Montreal, McGillQueen's University Press.

Irwin, Douglas (1996). Against the Tide An Intellectual History of Free Trade. Princeton, New Jersey, Princeton University Press.

Kay, John (1996).

Keil, Roger (1998). "Globalization Markes States: Perspectives of Local Governance in the Age of the World City." Review of International Political Economy(Fall).

Lasch, Christopher (1994). The Revolt of the Elites. Harper's Magazine: 39-49.

Lester, Richard (1998). The Productive Edge. New York, W.W. Norton.

Marshall, Herbert, Frank Southard, et al. (1936 and 1976). Canadian-American Industry: A Study in International Investment. Toronto, McClelland and Stewart.

Modeleski, George (1972). The Principles of World Politics. New York, The Free Press.

Nickell, Stephen (1997). "Unemployment and Labour Market Rigidities: Europe versus North America." Journal of Economic Perspectives 11:3(Summer): 55-74.

OECD (1997). OECD Surveys United States. Paris, OECD.

OECD (1996). Technology, Productivity and Job Creation Executive Summary. Paris, OECD.

OECD (1994). The OECD Jobs Study. Paris, OECD.

Ohmae, Kenichi (1996). The End of the Nation State. New York, Harper Collins.

Ostry, Slyvia (1998). Globalization and the Nation-State: Erosion From Above. Timlin Lecture, University of Saskatchewan. Regina.

Pauly, Louis W. (1997). Who Elected the Bankers? Surveillance and Control in the World Economy. Cornell, Cornell Univeristy Press. 
Pauly, Louis and Simon Reich (1997). "National Structures and Multinational Corporate Behaviour: Enduring Differences in the Age of Globalization." International Organization 51:1(Winter): 1-30.

Petrella, Ricardo (1996). Le bien commun Eloge de la solidarite. Bruxelles, Editions Labor.

Putnam, Robert (1993). “The Prosperous Community Social Capital and Public Life.” The American Prospect 13(Spring).

Rifkin, Jeremy (1996). The End of Work. The End of the Global Labor Force and the Dawn of the Post-Market Era. New York, Tarcher Putnam.

Rodrik, Dani (1997). "Sense and Nonsense in the Globalization Debate." Foreign Policy 107(Summer): 19-36.

Rodrik, Dani (1997). Has Globalization Gone Too Far? Washington, Institute for International Economics.

Rosenau, James (1996). The Dynamics of Globalization:Toward An Operational Formulation. Paper given at the International Studies Association, San Diego, June, 1997.

Rosecrance, Richard (1996). "The Rise of the Virtual State". Foreign Affairs

Ruggie, John Gerard (1982). "International Regimes, Transactions, and Change: Embedded Liberalism in the Postwar Economic Order.” International Organization 36(Spring).

Ruigrok, Winfried and Rob van Tulder (1995). The Logic of International Restructuring. London/New York, Routledge.

Sassen, Saskia (1996). On Governing The Global Economy. New York, University of Columbia Press.

Sassoon, Donald (1996). One Hundred Years of Socialism The Western European Left in the Twentieth Century. London, Fontana Press.

Stiglitz, Joseph E. (1998). More Instruments and Broader Goals: Moving Toward the PostWashington Consensus. The United Nations University, World Institute For Development Economics Research, Annual Lectures 2, Helsinki, The United Nations University.

Strange, Susan (1996). The Retreat of the State The Diffusion of Power in the World Economy. Cambridge, Cambridge University Press.

Streeck, Wolgang (1991). On the Institutional Conditions of Diversified Quality Production. Beyond Keynesianism. Egon Matzner and Wolfgang Streeck. Eds.Aldershot, England, Edward Elgar. 
Streeck, Wolfgang (1996). "Comment on Ronald Dore's Unions Between Class and Enterprise." Industrielle Beziehungen 3:2(Jahrgang): 187-196.

Weiss, Linda (1998). The Myth of the Powerless State. Ithaca, N.Y., Cornell University Press.

Wood, Adrian (1995). "How Trade Hurt Unskilled Workers." Journal of Economic Perspectives 9:3(Summer): 57-80.

Yergin, Daniel and Joseph Stanislaw (1998). The Commanding Heights the Battle Between Government and the Marketplace That is Remaking the World. New York, Simon and Schuster.

Wallerstein, Immanuel (1974). The Modern World System vol.I. New York, Academic Books.

World Bank (1997). The State in a Changing World. New York, Oxford. 